\title{
Stress Analysis of Traverse Beam Crane Hook Used in Steel Melting Shops of Steel Plant by ANSYS and CATIA
}

\author{
K. S. Raghu Ram*, D. Ajay Kumar \\ Department of Mechanical Engineering, Vignan's Institute of Information Technology, Visakhapatnam, A.P., India
}

Email address:

hodmechanicals@gmail.com (K. S. R. Ram)

*Corresponding author

\section{To cite this article:}

K. S. Raghu Ram, D. Ajay Kumar. Stress Analysis of Traverse Beam Crane Hook Used in Steel Melting Shops of Steel Plant by ANSYS and CATIA. American Journal of Mechanical and Industrial Engineering. Vol. 2, No. 1, 2017, pp. 37-40. doi: 10.11648/j.ajmie.20170201.16

Received: September 14, 2016; Accepted: November 21, 2016; Published: January 3, 2017

\begin{abstract}
The crane hook is fabricated with eight plates of $25 \mathrm{~mm}$ thickness and cut to the required size and dimensions as shown in the figure. The plates are riveted. Each crane hook carries 125 tones load. For this load the stress is found to be high and so high carbon steel with higher yield strength is suggested. After analyzing with different materials, a material is confirmed to be used for the manufacturing the crane hook. High Carbon Steel is suggested to be used as the material which is having high yield strength. A number of materials and designs are chosen for the use of crane hook, but from the different materials like Carbon steel, Cast Steel, SAE 1025Water quenched, SAE 1096 Oil Quenched steel and Stainless steel. Finally Carbon steel give the optimized results and the material is finalized for the fabrication purpose and the crane is working safely without any interruption since three years.
\end{abstract}

Keywords: Stress Analysis of Traverse Beam Crane Hook, Modeling, Meshing, Loading, Solution Finding, Material Selection for Longer Life

\section{Introduction for the Scope of the Present Work}

Theoretical and simulation analysis is carried out for the design of a traverse beam used in steel melting shop -II of Visakhapatnam steel plant. A crane fixed to a traverse beam is used in the steel melt shop to charge molten pig iron in a ladle to the steel converter. The analysis and simulation is carried out for the crane hook. The need for fixing the more life and high load carrying hook is the main criteria in this work [1-4].

\section{Main Work}

The crane hook is fabricated with eight plates of $25 \mathrm{~mm}$ thickness and cut to the required size and dimensions as shown in the figure. The plates are riveted. Each crane hook carries 125 tones load. For this load the stress is found to be high and so high carbon steel with higher yield strength is suggested. After using different materials, a material is confirmed to be used for the manufacturing the crane hook. High Carbon Steel is suggested to be used as the material which is having high yield strength.
Four materials and some designs are chosen for the use of crane hook, but from the different materials like Carbon steel, Cast Steel, SAE 1025 Water quenched, SAE 1096 Oil Quenched steel and Stainless steel [5-8]. Finally Carbon steel give the optimized results and the material is finalized for the fabrication purpose and the crane is working safely without any interruption since three years [9].

\section{Methodology}

The crane hook is constructed using eight plates of $25 \mathrm{~mm}$ thickness and cut to the required size and dimensions as shown in the figure 1. The plates are riveted [10-14]. Each crane hook carries 125 tones load. For this load the stress is found to be high and so high carbon steel with higher yield strength is suggested [15-19]. This is reflected in the table titled ANLYSIS.

The following are the various steps involved in the analysis of each pin used in traverse beam assembly [20-23]. The steps are as follows.

- Preferences $\rightarrow$ structural $\rightarrow$ ok

- Pre-processor:- It involves

a. Definition of element: - A 8 node 185 structural element, SOLID brick 8 node 45 is chosen for the analysis of the 
pin. The detailed properties of the element are discussed a little later.

\section{ELEMENT TYPE $\rightarrow$ ADD/EDIT/DELETE $\rightarrow$ ADD $\rightarrow$ SOLID BRICK 8 NODE $45 \rightarrow \mathrm{OK}$}

b. Real constants:-since the model is a 3-D solid, there are no real constants.

c. Material properties:-The material selected is $\mathrm{Fe} 800$ indicates tensile stress of the material, ' $\mathrm{W}$ ' indicates that the material is weld able, 'c' indicates that the steel is killed. The young's modulus of the material is $8 \mathrm{e} 8$ $\mathrm{N} / \mathrm{mm}^{2}$, poison's ratio is 0.3 .

\section{MATERIAL PROPERTIES $\rightarrow$ MATERIAL MODELS.}

d. Modelling: - after defining the material properties, the next step is the creation of the model which constitutes a major part of the analysis.

The solid model which is created using CATIA v5 is imported into ANSYS. The IGES extension file is imported from catiav5 in ANSYS.

e. Meshing: it is the process of discrediting the model into finite elements of simpler geometry. The material properties and the governing relationships are considering the loading and constraints results in a set of equations. Solving these equations by numerical method gives us an approximate behaviour of the model.

- SOLUTION:-

This is the phase where the loads and constraints are applied.

$$
\begin{aligned}
\text { SOLUTION } & \rightarrow \text { ANALYSIS TYPE } \rightarrow \text { NEW ANALYSIS } \\
& \rightarrow \text { STATIC } \rightarrow \text { OK. }
\end{aligned}
$$

a) CONSTAINTS:- the constraints are applied at both the ends of pin.

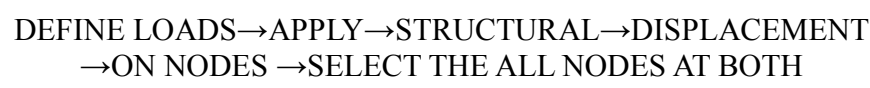

b) LOADS:-

LUMPED LOADING: - it means that the total loading of 125 tons on middle of pin.

\section{DEFINE LOADS $\rightarrow$ FORCE/MOMENT $\rightarrow$ ON NODES $\rightarrow$ SELECT THE AREA OF CENTRE OF PIN $\rightarrow \mathrm{F}_{\mathrm{Y}} \rightarrow$ APPLY $\rightarrow$ OK}

Table 1. Showing the Analysis Process carried out in the ANSYS Program.

\begin{tabular}{ll}
\hline Object Name & Mesh \\
\hline State & Solved \\
Defaults & \\
Physics Preference & Mechanical \\
Relevance & 0 \\
Sizing & \\
Use Advanced Size Function & Off \\
Relevance Center & Coarse \\
Element Size & Default \\
Initial Size Seed & Active Assembly \\
Smoothing & Medium \\
Transition & Fast \\
Span Angle Center & Coarse \\
Minimum Edge Length & 9.9365 e-006 m \\
Inflation & \\
Use Automatic Inflation & None \\
Inflation Option & Smooth Transition \\
Transition Ratio & 0.272 \\
Maximum Layers & 5 \\
Growth Rate & 1.2 \\
Inflation Algorithm & Pre \\
View Advanced Options & No \\
Advanced & \\
Shape Checking & Standard Mechanical \\
Element Midside Nodes & Program Controlled \\
Straight Sided Elements & No \\
Number of Retries & Default (4) \\
Extra Retries For Assembly & Yes \\
Rigid Body Behavior & Dimensionally Reduced \\
Mesh Morphing & Disabled \\
Defeaturing & \\
Pinch Tolerance & Please Define \\
Generate Pinch on Refresh & No \\
Automatic Mesh Based Defeaturing & On \\
Defeaturing Tolerance & Default \\
Statistics & \\
Nodes & 65409 \\
Elements & 37404 \\
Mesh Metric & None \\
\hline & \\
\hline & \\
\hline
\end{tabular}

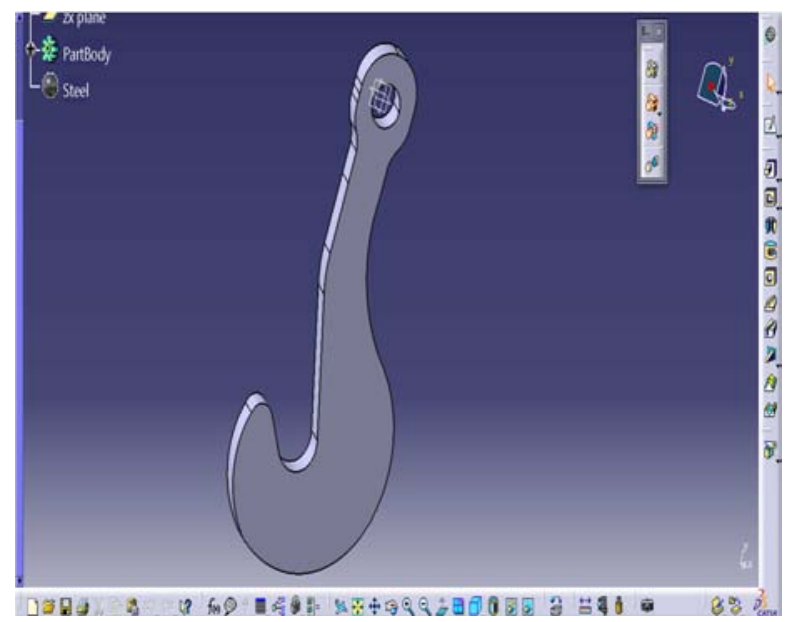

Figure 1. Showing the CATIA Model of the crane used as per the dimensions of the transverse beam. 
Table 2. Showing the material details of the crane hook.

\begin{tabular}{llll}
\hline Name of the item and size & MATERIAL & QTY & TOTAL WEIGHT(Kg f) \\
\hline PLATE 3642.5X1570X25THK & STEEL & 8 & 4021 \\
\hline
\end{tabular}

\section{Results and Discussion}

Results are obtained from analysis of Crane hook using ANSYS for 125tons load acting on Crane hook. The maximum von-mises stress is $348.56 \mathrm{~N} / \mathrm{mm}^{2}$ and the maximum Principal stress is $356.49 \mathrm{~N} / \mathrm{mm}^{2}$. Hence material No.5 is selected for Crane Hook at 125 tons load by using a factory of safety of 4 .

Table 3. Showing the Mechanical properties of different carbon steel material for Crane Hook.

\begin{tabular}{|c|c|c|c|c|c|}
\hline \multirow[b]{2}{*}{ S. No } & \multirow[b]{2}{*}{ Material } & \multirow{2}{*}{$\begin{array}{l}\text { Young's Modulus } \\
(\mathrm{N} / \mathrm{mm} 2)\end{array}$} & \multirow[b]{2}{*}{$\begin{array}{l}\text { Yield strength } \\
\text { (N/mm2) }\end{array}$} & \multicolumn{2}{|c|}{ Factor of safety $=$ 4Poisson's Ratio $=0.3$} \\
\hline & & & & $\begin{array}{l}\text { YieldStrength---------von-Mis } \\
\text { esstress }\end{array}$ & $\begin{array}{l}\text { Yield Strength---------Principal } \\
\text { Stress }\end{array}$ \\
\hline 1 & Carbon steel & $2 \times 105$ & 250 & 0.71 & 0.70 \\
\hline 2 & Cast steel, soft & $2 \times 105$ & 414 & 1.18 & 1.16 \\
\hline 3 & SAE 1025 , water quenched & $2 \times 105$ & 621 & 1.78 & 1.74 \\
\hline 4 & SAE 1096,oil quenched & $2.07 \times 105$ & 896 & 2.57 & 2.51 \\
\hline 5 & 18-8 Stainless steel $0.12 \% \mathrm{C}$. & $2.07 \times 105$ & 1380 & 3.96 & 3.87 \\
\hline
\end{tabular}

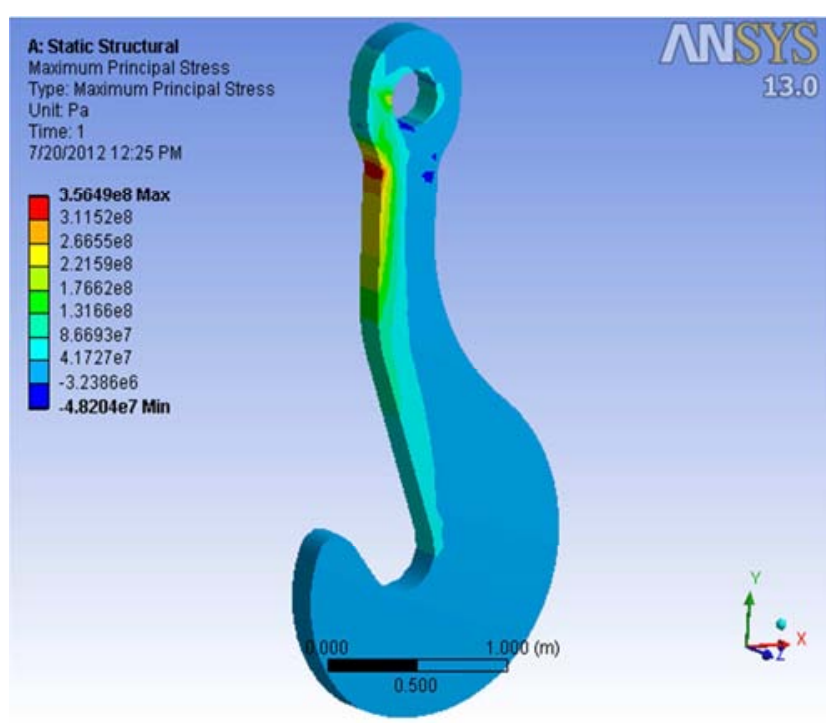

Figure 3. Showing the principal stresses along the crane hook.

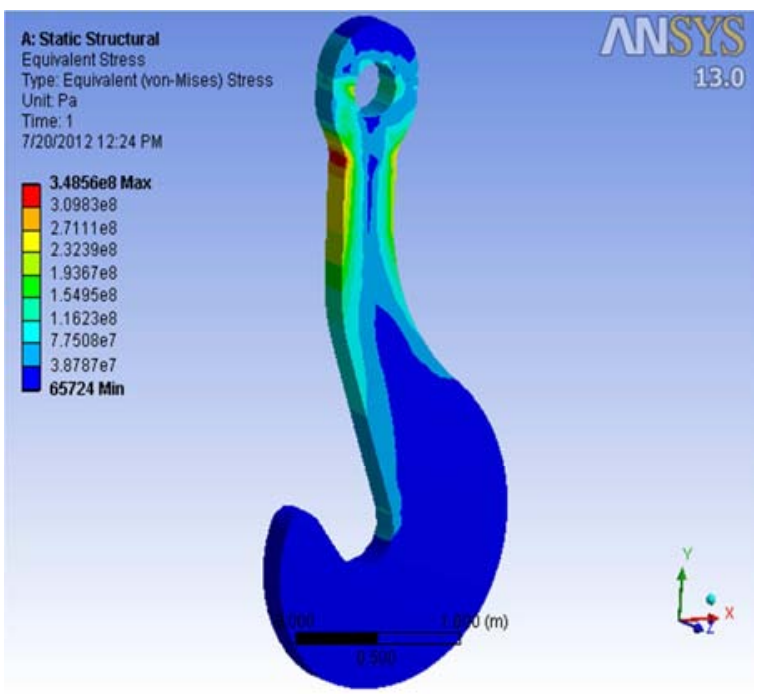

Figure 4. Showing the Equivalent Stress acting on Crane hook from ANSYS analysis.

\section{Conclusion}

a. A traverse beam crane hook carrying a load of 250 tons has been designed, fabricated, tested and put into service in SMS-II (Steel Melting Shop-II) of Visakhapatnam Steel Plant.

b. Theoretical analysis has been carried out with the aid of CATIA and ANSYS software to predict the stress exerted on the traverse beam crane hook. This theoretical analysis was carried out before applying the actual load on the crane with traverse beam.

c. Since the payload is hot molten metal and any failure of the components could be disastrous in terms of human life, injury, and other economic costs, a factor of safety of 4 was considered in the design process.

d. Manual calculations of von Mises and principal stresses were also carried out. These values compare fairly well with the ANSYS results for all components. $182 \mathrm{MPa}$ with manual calculation vs. $169 \mathrm{MPa}$ of ANSYS results for pin 1; $163 \mathrm{MPa}$ with manual calculation vs $181 \mathrm{MPa}$ with ANSYS for pin 2).

e. Material selection was done from a set of available materials and choice was made based on that material which exceeded the minimum stipulated factor of safety.

\section{Acknowledgement}

The authors express sincere gratitude to Dr. PILAKA MURTY, Professor in Department of Mechanical Engineering, GVP College of Engineering (Autonomous), Visakhapatnam for his constant support and encouragement for completion of this work and also extend sincere thanks to Mr. M.R.S. SUDESH KUMAR, Manager, Plant Design Department, Visakhapatnam Steel plant for expert guidance, constant encouragement and support during all phases of work. Prof. V. DHARMA RAO, Department of Mechanical Engineering is the key person for his guidance and valuable suggestions. 


\section{References}

[1] Veenitha Yalavarthy, Ramu Kandregula and K. S. Raghu Ram, "Experimental Analysis of Stress, Strain and deformation on different types of Conveyor belt pulleys. An analysis conducted at Visakhapatnam Steel Plant" International Journal of Advances in Basic Sciences, 10(1), January 2016, Pages: 715-719.

[2] "AISC Specification for structural steel buildings (AISC 360-05)", Chicago (IL): American Institute of Steel Construction, March 9, 2005.

[3] Trahair NS, "Flexural-torsional buckling of structures", Boca Raton. London: E\&FN Spon.; 1993.

[4] Timoshenko SP, Gere JM. "Theory of elastic stability", 2nd edition New York: McGraw-Hill; 1961.

[5] Nethercot DA, Rockey CK, "Finite element solutions for the buckling of columns and beams", International Journal of Mech. Sciences 1971.

[6] Galambos TV, "Guide to stability design criteria for metal structures", Structural Stability Research Council. 5th edition, New York: John Wiley \& Sons; 1998.

[7] Kirby PA, Nethercot DA, "Design for structural stability", Canada, Granada. London; 1979.

[8] Mohebkhah A, "The moment-gradient factor in lateral-torsional buckling on inelastic castellated beams", Journal of Constructional Steel Research 2004; 60: 1481-94.

[9] Samanta A, Kumar A, "Distortional buckling in mono symmetric I-beams", Thin-walled Structures (2006), Vol.44:51-6.

[10] Amin Mohebkhah, "Lateral buckling resistance of inelastic I-beams under off-shear center loading", Thin-Walled Structures (2011) Vol. 49: 431-436. journal homepage: www.elsevier.com/locate/tws

[11] Ch.Siva Rama Krishna, K. S. Raghuram, R. Arvindkumar," Analysis of Residual Stresses on Tubular Welded joints", IManager's Journal On Mechanical Engineering, vol. 5, No. 3, May-July 2015

[12] ANSYS. User's manual, version 5.4. ANSYS Inc. 201Johnson Road, Houston, PA, 15342-1300. 1998.
[13] M. Şimşek, "Static analysis of a functionally graded beam under a uniformly distributed load by Ritz method,'International Journal of Engineering and Applied Sciences (IJEAS) Vol. 1, Issue 3(2009)1-11.

[14] Reddy JN, "Energy and variational methods in applied mechanics", New York: John Wiley; 1984.

[15] MesutSimsek, "Vibration analysis of a functionally graded beam under a moving mass by using different beam theories", Composite Structures 92 (2010) 904-917, journal homepage: www.elsevier.com/locate/compstruct.

[16] J.C. Ekvall, "Static Strength Analysis of Pin-Loaded Lugs", J. AIRCRAFT VOL. 23, NO. 5.

[17] K.S. Raghu Ram, PDSN Deepak, Ch. Siva RamaKrishna, B. Avinash Ben "Manufacturing and Delamination Study of Drilling on Glass Fiber Reinforced Plastic(GFRP)" International Journal of Advances in Basic Sciences, 9(36) December 2015, Pages: 391-395.

[18] Katherisan, K., Hsu, T. M., and Brussat, T. R., "Advanced Life Analysis Methods Volume II-Crack Growth Analysis Methods for Attachment Lugs," AFWAL-TR-84-3080, Sept. 1984.

[19] K. Mahadevan and K. Balaveera Reddy, Design Data Hand Book, Edition-3.

[20] R.C. Juvinall and K.M. Marshek, "Fundamentals of Machine Component design", $3^{\text {rd }}$ edition, Wiley India.

[21] D. Ajay Kumar "Design and Analysis of traverse Beam pin in Steel Melting Shop" Australian Journal of Basic Applied Sciences, 9(36) December 2015.

[22] K.S. Raghu Ram, Nellipudi Laxmi, Ch. Siva Rama Krishna, B. Avinash Ben "Applicability of rule of mixtures to particle matrix Metal Matrix composite material" International Journal of Advances in Basic Sciences, 9(36) December 2015, Pages: 509-513.

[23] Y. Jaya Santhoshi Kumari, K. S. Raghuram and Ch. Siva Ramakrishna; Aluminium fly-Ash Metal matrix composites A Value added material made from thermal power plants waste disposal"; international conference titled "'Energy Research and Environmental Management: An Innovative Approach (ISBN:978-81-930585-2-7)" conducted at JN University,NewDelhi on by KrishiSanskritiPublications,New Delhi on 14-15 February 2015 Page No:85-89. 